methods of stacking fruit in the holds of ships. Mr. N. F. Holmes, in connexion with the transport of Australian citrus fruit, discussed fungal spoilage and loss of flavour in relation to age of the fruit, and the value of various methods as tests of the state of maturity, while Mr. D. J. Dreyer described experiments relating to mechanical damage to South African pears. With reference to the gas storage method, which has been rapidly taken up by some English growers of apples in the last few years, Dr. C. West advised a certain amount of caution, as much research work still remains to be done before the method is placed on a sound basis. Finally, papers of a fundamental nature were read by Dr. A. S. Horne and by Mr. R. Gane, the former discussing the results of a quantitative study of the resistance of apples to fungal invasion and the latter dealing with some interesting effects of ethylene gas on the respiration and maturing of banana fruit.
In the final session, Prof. E. E. Cheesman directed attention to the pressing need for greater facilities within the Empire for the collection and classification of crop varieties and related species. The menace of Panama disease and of witch-broom disease to banana and cacao cultivation respectively makes it imperative that wholehearted attempts should be made to discover or to breed suitable varieties of the crop plants resistant to these diseases. The work is seriously handicapped at the moment by the lack of adequate facilities.

An interesting feature of the Conference was a series of exhibits comprising, in addition to the illustrations of South African plants already mentioned, a collection of types of cultivated Sorghum and of cowpea (Vigna sp.) prepared by the staff of the Royal Botanic Gardens, Kew, and an exhibit illustrating Linnæus's development as a botanist arranged by the Librarian of the Linnean Society.

\title{
Conference of Empire Meteorologists
}

$\mathrm{T}$ WENTY-FIVE Dominions and Colonies were represented at the third Conference of Empire Meteorologists which was in session at the Meteorological Office, South Kensington, on August 12-21. Six years have elapsed since the previous conference and there have been important changes during that period, both in the organisation of colonial meteorological services and in the demands made upon them for data, either for home consumption or for international dissemination. There were two main reasons for calling the conference, first to give the directors of services an opportunity of discussing their problems before proceeding to the International Conference of Directors to be held at Warsaw this month; secondly, to discuss the meteorological arrangements necessary to meet the Government's requirements in connexion with the Empire air-mail scheme.

At the same time, the meetings provided an opportunity for the exchange of views on many other questions of a general character. In meteorology, problems of co-ordination are not less important than purely technical problems. It is, therefore, very necessary that the administrators of meteorological services should meet from time to time to discuss these matters. Within the Empire we have a wide diversity, not only in climate but also in the administrative arrangements for handling meteorological data. A meeting of Empire meteorologists thus provides a means for considering problems from every angle, and has a special value for that reason.

At the opening meeting on August 12, the delegates were welcomed by Sir Henry Lyons, vice-chairman of the Meteorological Committee. Mr. J. Patterson, director of the Canadian Meteorological Service, was elected president of the Conference. At the first business meeting, the Government's policy in regard to the Empire air-mail scheme was outlined. This scheme involves both day and night flying, and adequate meteorological services must be a fundamental part of the necessary ground organisation. Linked up with the question of organisation are such technical matters as the making of synoptic charts on a uniform plan, the coding of reports from land. stations and ships and the choice of hours of observation. Air-mail pilots are familiar nowadays with synoptic charts, and it is important that they should be able to consult up-to-date charts at their ports of call. It is also important that a symbol they see on a chart in one country should have the same meaning as a similar symbol on a chart they see in another country. The delegates will have to consider the international aspect of this matter of symbols at Warsaw, and the discussion in London proved very useful.

Questions connected with aviation and with synoptic meteorology occupied the first few meetings. These were followed by discussions on meteorology for the Army and for the Navy, instruments, upperair observations, marine meteorology, geophysics, climatology and agriculture, and seasonal forecasting. The use of upper-air data has assumed increased importance with the advent of air-mass analysis for the purpose of synoptic diagnosis. In many colonies there are special difficulties, however, in the way of obtaining the data. One difficulty is that of procuring hydrogen for the inflation of pilot balloons, and it was of interest to learn how the difficulty is being met in Canada by the use of a portable electrolytic generator, and in East Africa by an ingenious chemical generator, the essential part of which has been adapted from a commercial pressure-cooker.

In connexion with geophysies, the Conference passed a resolution recommending the establishment of a station at Chesterfield Inlet, Hudson's Bay, Canada. This station would be in near proximity to the North Magnetic Pole and its situation would also be very favourable for auroral studies. The conference also recommended the establishment of a station at Tristan da Cunha, observations from which, situated as it is about midway between the Cape of Good Hope and South America, would be of great value.

The discussions on climatology and agriculture began on August 19. Perhaps the most interesting subject in these categories was that of the broadcasting of climatological data. Students of world climatology have previously been handicapped 
seriously by the difficulty of obtaining current climatological data. The monthly summaries issued by the various services are often published many months in arrear, and it has thus been impossible to put together an up-to-date picture of the climatological conditions all over the land areas of the globe. Lieut.-Colonel E. Gold gave an outline of a scheme for the broadcasting of brief data from selected stations in each country on the fifteenth of the month following that to which the data refer. This scheme will come before the international conference at Warsaw ; its successful realisation would be an advantage not only to climatologists but also to business men who require recent information in regard to the general weather conditions in distant lands.

The subject of seasonal forecasting gave rise to an interesting discussion. Everyone of course recognises the great advantages that would ensue if some reliable method could be evolved for forecasting the general character of the weather some weeks or months in advance. The existing methods were brought under review, but it can scarcely be claimed that we are within sight of a solution. An elaborate preliminary study of the main causes of variation may, as in the case of the monsoon rainfall of India, result in the derivation of an equation from which a forecast can be made with a certain degree of success. The general view, however, was that none of the methods hitherto explored had given results good enough to justify the inauguration of an official service of long-range forecasts.

E. G. B.

\section{Educational Topics and Events}

GLasgow.-The King has been pleased, on the recommendation of the Secretary of State for Scotland, to approve the appointment of Mr. Duncan MacCallum Blair, professor of anatomy and Dean of the Medical Faculty, King's College, University of London, to be regius professor of anatomy in succession to Prof. T. H. Bryce, whose resignation takes effect on September 30.

COLLEGE library administration carried to a high pitch of activity is exemplified in Columbia, Missouri, where librarians, spurning the role of mere custodians of books, make it their business to become acquainted with and contribute to class-room instruction and make systematic provision for acquainting lecturers with the library's resources with reference to current work. They visit classes, participate in faculty meetings, hold instructional conferences with students and conduct introductory orientation classes. Collections of books are disposed where they are most easily accessible to students both in common-rooms, in class-rooms, in laboratories and in hostels. Conversely, the instructional staff, besides encouraging students to make the most of the library's resources, act as assistant librarians and give regular instruction in the technique of reading, especially the timed reading exercise followed by a comprehension test. In fact, reading is recognised as the student's chief tool, and the college holds itself responsible for seeing that every student becomes highly skilled in the use of it. The head librarian is at the same time dean of instruction and his aim is to make the library the "heart of the college". The above facts are gleaned from correspondence in School and Society of May 18.

\section{Science News a Century Ago}

\section{Consumption in Man and Animals}

IN a long review of "A Treatise on Pulmonary Consumption" by Dr. James Clark, M.D., F.R.S., the Athenaeum of September 5, 1835, said: "The Chapter on the Statistical History of Consumption contains many curious facts, and is accompanied by several valuable tables affording much matter of interesting reflection to the political philosopher. It appears that more than one-fourth of those who die from birth to puberty are affected with tuberculous disease; that the greatest number of deaths from consumption occur between the age of twenty and thirty... the mortality being probably at its maximum at thirty and gradually diminishing from that age. . . The chapter on the disease in animals affords much interesting information... . In the gardens of the Zoological Society in Regent's Park Mr. Owen has found the disease in the tiger, the Persian lynx, the paradoxure gennet, the civet cat, the Indian ichneumon, the brown coati mondi, the Nepâl bear of the Himalayas, the American tapir, the American elk, in various monkeys, in tho Eskimaux dog and in the lungs of the Python tigris".

\section{The Zoological Society}

Aт a meeting of the Zoological Society held on September 8, 1835, Thomas Bell being in the chair, "a marmazet was presented from Mr. Moore of Rio Janeiro, the first that has ever been seen alive in this country. This, the most diminutive species of the monkey tribe, is about the size of a small rat, and even when full grown can be put into a half-pint tumbler. The greatest singularity is its large bushy tail, in which it completely envelopes itself when it retires to repose, to screen itself from the cold. The countenance of this species is that of an old man; and the one presented to the Zoological Society is said to bear an exact resemblance to that of a celebrated French diplomatist". (The Times, September 14, 1835.)

\section{Capt. Back's return from the Arctic}

ON September 10, 1835, The Times announced the arrival in Liverpool of Capt. George Back on his return from his journey in search of Capt. John Ross, and the following day quoted the following passages regarding Back's expedition from the Montreal papers : "During the first winter the expedition had to endure great privations, owing to the scarcity of food and the severity of the weather. Captain Back is the first European who has visited the Great Fish River and examined its course to the Polar Seas. Its very existence was doubted by many geographers. It is said to be large, but dangerous navigation; greatly impeded by ice; it falls into the Polar Sea. Further than this, we only know that the party of intrepid travellers had to encounter every obstacle to which Polar navigation is liable, and we are led to believe that immense masses of ice, with severe weather finally arrested their progress. Captain Back will, we believe, have much interesting in. formation to communicate respecting his observations on the Aurora, the changes on the needle as he drew northward, etc. The extreme cold he experienced, we learn, was 70 degrees below zoro. The expedition returned to Fort Reliance which Captain 